\title{
JLミCOV
}

Journal of Life Economics

Cilt / Volume 7, Say1 / Issue 4, 2020, pp. 323-330

E - ISSN: 2148-4139

URL: https://www.journals.gen.tr/jlecon

DOI: https://doi.org/10.15637/jlecon.7.024

Araştırma Makalesi/Research Article

\section{JAMAICAN CRIME AND ECONOMY}

\author{
Seda YAZGAN HADZIBULIC* \\ * Northeastern Illinois University, Graduate Student Political Science \\ UNITED STATES, e-mail: sedayazgan87@gmail.com \\ ORCID ID: https://orcid.org/0000-0002-7194-4805
}

Received: 15 June 2020; Accepted: 15 October 2020

\begin{abstract}
This research paper examines an overview of literature on the most recent issues that are allied to crime and violence in Jamaica. They have been an issue which has affected the Caribbean as a whole but due to the islands many social and economic problems, it has shown an increase in crime and violence most noticeably in Jamaica. This issue has caused millions of people to live in fear due to the constant and never-ending crime and violence. The horrors of violence and crime has undoubtedly had a more profound and significant negative impact on the young population. My research will focus on the aspects of violence and crime in Jamaica. This paper will also cover the general conditions in Jamaica, the organized crime and the conventional violence, and how the impact of the crime has had an effect on economic growth. My conclusion will focus on the policies which these countries have to change that will significantly reduce crime and violence and as a result will provide a better social and economic future for all of its citizens. The aim of this research is to have a broader understanding about crime and violence in Jamaica and to raise global awareness about their conditions and the humanitarian problems.
\end{abstract}

Key Words: Violence, Organized and Conventional Crime, Economic Growth, Jamaica, Caribbean.

Jel Codes: A13, E71 


\section{CRIME}

Countries that have high crime rates generally have a population that is struggling economically, academically and socially. The governments of Jamaica have continually failed in most cases in providing basic programs for its citizens thus resulting in a high crime rate. The most prevalent are organized crimes like drug trafficking, kidnapping, depravity, as well as the conventional crimes of violence. Jamaica's crime problems are brought on by gangs and organized crime which are major factors of violence particularly homicide. (Morris and Graycar 2011) Those in charge of organized crime have used Jamaica's economic problems to their advantage by recruiting the young from poor communities with the promise of wealth that would get them out of poverty and have also recruited corrupt local and state governments such as police and politicians.

The high murder rate and poverty can be traced back to a lack of a family structure which has a missing father figure possibly to crime such as murder or incarceration. The result is a harder economic situation for the mother providing for the family as 42 percent of Jamaican households are led by a woman.(UN 2017) The 2015 stats on young Jamaicans living below the poverty line show that 27.8 percent of those considered adolescents aged 10-19 years old live below the national poverty line, followed by 26.2 percent of youth aged 15-24 years old and 18.8 percent of young adults 25-34 years old.(Lee and Delatie-Budair 2018) Due to the young population living in poverty and crime, it was reported that in 2013 Jamaica had a total of 238 gangs which was responsible for 79 percent of all the murders and guns are responsible in some cases as high as 76 percent of murders committed.(Harriot and Jones 2016) The author of Confronting the Don, Glaister Leslie writes that most firearms seized in Jamaica are traced back to three US counties - Orange, Dade, and Broward - in the state of Florida, all of which have large Jamaican populations. If there is a shortage of weapons coming in from the US, the gangs can then turn to the corrupt local and state officials. The discovery in early 2010 of large amounts of illegal ammunition and firearms - all originating from the police force's central armory - has conclusively linked security forces to the distribution of ammunition and weapons to criminals. (Leslie 2010) The organized gangs of Jamaica have also made connections to Haiti's organized crime. Haiti's political and economic situations are in many ways similar to Jamaica's which has resulted in the cooperation between its organized crimes $s$ it is alleged that Jamaica has traded marijuana for guns with Haiti since 2007.(Leslie 2010) With such ease in access to weapons the high numbers in murder is expected as Jamaica's 1,326 murders in 2019 gave it a homicide rate of 47.4 per 100,000, marginally higher than 2018's rate of 47.(Assmann and O'Reilly 2020) Due to the high murder and crime rate, ordinary citizens seem to have lost their faith in the government and some have put their trust in "the Dons" for security which comes with a price as it gives more power to the local gangs as they are supported by corrupt officials at local and government level. Dons exercise control over a gang or a community are linked to politicians and are both dependent on one another, as the politicians rely on the Dons during the election to bring in the votes from those in their neighborhood of control, and in return the politicians may provide housing and job programs while allowing the don to become the rule of law in his community with impunity.(Leslie 2010) This allows for many backdoor deals between the politicians and the Dons and is not a secret amongst Jamaican's, but what must be brought to light is that this relationship allows for more crimes to be committed as the Dons are given the greenlight to act as the police and the judge within their neighborhood line of control which links them to Jamaica's high crime and homicide levels.(Jaffe 2019) If the Dons organized crimes and gangs can reach as high as government politicians, they also have control on a local level as organized crime in Jamaica point to members of the police (the Jamaican Constabulary Force - JCF) being corrupted by individuals in the criminal underworld who benefit from police protection and facilitation of their illicit activities.(Leslie 2010) The 
Jamaican government's own 2007 National Security policy report admits that due to the corruption the national security is under threat. That acknowledgement has not had any effect on the politicians as their respect for the Dons is on full display for all when the Dons are on the receiving end of the violence and are murdered, the high-ranking ministers and political officials are seen in attendance at the funerals of prominent Dons, some of whose memorial services received official state authorization to be held at the National Arena, a recognized venue ordinarily reserved for public events.(Johnson and Soeters 2008) As the Dons are looked upon by their neighborhood community to provide welfare services and in some cases protection of their neighborhood, they use that service as a disguise to commit crimes not only locally but they also reach far and wide as they are known to operate as a mafia organization as their crimes provide funding for continued criminal activities. Jamaican Dons are today multimillionaires, accumulating significant wealth from three broad streams of organized crime: (1) illicit trafficking in narcotics, guns and contraband; (2) money laundering, fraud and reinvestment of illicit profits into the formal economy; and (3) extortion, especially the skimming of public works contracts, illegal gambling and burglary.(Johnson and Soeters 2008) With such wealth to display, it is easy for the young and impoverished generation to want to join organized crime and gangs and commit crimes in hopes of one day reaching the near impossible dream of becoming a Don, instead they increase Jamaica's crime statistics or end up being a murder statistic Interestingly, while the Dons do provide some welfare services for their community, nearly three in four of all victims report that they were victimized within their own neighborhood,(Harriott, Lewis, Zechmeister 2014) while the reported 79 percent of the homicides that occurred in 2013 were gang related which both of the statistics can be directly linked to the Dons criminal enterprise.(Harriot and Jones 2016) This is just one of the reason why the murder rate continues to be so high as Jamaica's 1,326 murders in 2019 gave it a homicide rate of 47.4 per 100,000, marginally higher than 2018's rate of 47 per 100,000. (ASSMANN AND O'REILLY 2020) Due to the out of control violence and murders, in January of 2018 the Government of Jamaica declared States of Emergency and also instituted Zones of Special Operations for several parishes including the Kingston Metropolitan Area and the parish of St. James.(OSAC 2019) Another important aspect of the crime not to be overlooked is that Jamaica's geographical position, lying as it does between the world's primary source of cocaine and heroin in the south and the largest consumer markets in the north, makes it a convenient country for drug trafficking.(Leggett, van Bronkhorst, Demombynes et al. 2007) The organized crime and gangs are well aware of the need for control in receiving and exporting the drugs which then results in high crime and murders rates. The difficulty in reducing crime can also be attributed due to the fact that two of the three major drug corridors into the US pass through the Caribbean as Jamaica is the largest Caribbean supplier of marijuana to the US as well as being a significant transit point for cocaine trafficked from South America to North America and Europe.(Witbooi 2020) With such high crime rates residents of impoverished neighborhoods must weigh the trade-off between the access to some welfare programs and the high crime that is prevalent in their neighborhood all as which both are the works of the Dons.

For many the answer is clear as 41.8 percent of Jamaicans have a negative perceptions of household economic situation and when it comes to crime, violence or insecurity, 49.8 percent of Jamaicans identify as the most serious problem facing the country (Harriott, Lewis, Zechmeister 2014) The high rates of homicides are not all due organized crime. In 2013, 6.3 percent of all murders were due to domestic violence in which most of the murder victims were women and also the rate of reported rapes was 30 per 100,000 inhabitants with 25.9 percent being committed against those that are 14 years or younger. (Harriot and Jones 2016) 


\section{CRIME AND THE RELATIONS ON THE ECONOMIC GROWTH}

The high number of crimes committed have a cost not just on lives lost but also on Jamaica's overall economy. In 2013 Jamaica tried to have strategic and stable reforms to improve the economic growth, reduce the debt and gas price. While they are making some progress, they still have more to do as 17 percent of its 2.93 million people live in poverty and must address issues of its current 7.8 percent unemployment rate which would help in decreasing high levels of crime and violence. (World Bank 2019) Jamaica high rates of crime and homicide discourages potential investors that would help in its economic growth. According to 2014 statistics, the crime related cost for Jamaica is equal to 3.99 percent of their GDP. (Jaitman, Caprirolo, Ochoa, et al. 2017) For Jamaica, the 3.99 percent loss in its economy is a huge number which only makes it more difficult to address the burden of debt repayment which has kept them from stabilizing its economy. Losing potential outside investment due to high crime rates, Jamaica must also find a way to budget and maintain the jails and correctional facilities. Jamaican economic problems also reflect on its set budget for the Department of Correctional Services (DCS). The DCS in 2012-2013 had a budget of JMD 4.6 billion, which increased to JMD 4.9 billion in 2013-2014, which was slightly reduced to JMD 4.8 billion in 2014-2015.(HARRIOT AND JONES 2106) To get a better look at the economic situation Jamaica and how it does its budget, in 2014-2015 Jamaica budget total was JMD \$539,350,151 and of that amount 3 percent of the budgeted was allocated for the National Security in which the Department of Correctional Services and police force falls under, 19 percent for of the budget was allocated to education, while 33 percent of its budget went to repayment of debt. (Dig 2014) With a struggling economy and high debt it does not have the resources to invest in measures that would reduce crime such as education and the correctional service that could also provide or add additional programs that would assist in rehabilitating offenders. Since its 2013 announcement of economic reforms, while there may be some small positive changes, it continues to have a significant expenditure on debt servicing. According to the Ministry of Finance and Public Service of Jamaica 2020-2021 budget report, out of the JMD \$852.68 billion its budget, debt is still a significant issue as 34 percent or a total of JMD \$287.84 billion is allocated to debt servicing. In the same budget report, the National Security Department was allocated 9 percent which is JMD $\$ 93.96$ billion and the Education Department a total of JMD $\$ 118.55$ billion which is 14 percent of the total budget expenditure. Looking at those numbers, it is evident that while Jamaican budget expenditure has increased, the total percentage allocated for education has decreased while there was an increase for the National Security department and Department of Correctional Services. Outside investors are sure to factor in Jamaica's commitment in resources in bringing down the crime rate. If outside investors and big corporations were to do business in Jamaica they would more than likely need to move some of their staff to Jamaica while also hiring Jamaican citizens to fill other positions. Potential investors are sure to balk at such a move due to Jamaica's crime problems, especially the threat of kidnapping which can happen in any part of Jamaica as the organized crime has its own highend kidnapping gangs that target high-profile high-net-worth individuals.(OSAC 2019) While the Jamaican government has its attention on gangs and organized crime in hopes of reducing crime to attract outside investors, they also must deal with local citizens that are not part of organized crime but due to the economic situation have resorted to illegal activities in making ends meet. As an example, in the illegal activities in the fishing industry, Jamaica loses the economic value of USD \$10 million worth of spiny lobster, conch and finfish annually due to foreign industrial fishers who engage in illegal, unreported and unregulated (IUU) fishing. (Neil 2018) Illegal - unregulated fishing is something that countries around the world have to deal with as well but with Jamaica trying to get itself out of debt it cannot afford to lose money. When it comes to tourism, it is no secret that it is the most important economic activity in Jamaica as the total contribution to the country's GDP was estimated to be 30.3 percent in 2016 
in which directly and indirectly supported around 318,500 jobs, around $27.5 \%$ of the labor force.(WTTC 2017) Jamaica's tourism continues to help its struggling economy as 2019 stats show that tourism contributed 31.1 percent to its GDP and an increase in travel and tourism related jobs to 406,100 which accounted for 32.8 percent of its labor force.(WTTC 2020) The United States accounts for 65 percent of Jamaica's visitors (WTTC 2020) and a possible explanation for Jamaica's tourism not making a bigger gain could be due to the US Department of State issuing a 2019 Jamaica travel advisory due to crime.(USDOS 2019) Interestingly, (Matakovic and Matakovic 2019) writes that a drop in tourist arrivals was particularly evident in arrivals of tourists from Europe, which, unlike other Jamaica tourists, mostly from the United States, did not use the all-inclusive resorts that mostly leave foreign tourists without contact with the outside world and also with the crime. More intense contacts with the local community resulted in increased victimization of European tourists, and consequently, this victimization influenced their decision to revisit Jamaica.

\section{CONCLUSION}

The root of the problem in Jamaica is the corruption on the local and government levels in which its officials collaborate with organized crime and gangs. This collaboration which supposedly provides services to poverty-stricken neighborhoods is a cover that only enables organized crime and gangs to continually commit crime while it keeps local and government officials elected to office. If the Jamaican government wants to decrease its record crimes and homicides, it must root out the problem from within its own government which can then make it easier in substantially decreasing the high crime rates of all kinds. Until then is done, the government of Jamaica must find a way to allocate more of its funding and resources for the National Security which is in charge of the police and Department of Correctional Services in policing and providing security to neighborhoods and rehabilitating its incarcerated youth as well as education. By doing so, it will show to those outside of Jamaica that are paying attention, that the Jamaican government understands that they must invest in themselves before asking investors to invest in them. Special attention should be brought and solutions must be found to the economic debt problem which has burdened the Jamaican economy. With tourism providing a third of its economy, the Jamaican government has to make sure that it sustains its growth while lowering the crime rates and paying down the debts. If it can root out the corruption, it will lead to economic growth not just in tourism but will also have the attention of outside investors and big corporations that have been eager to do business in Jamaica 


\section{REFERENCES}

HARRIOTT, A., BALFORD, L., and ELIZABETH, J. Z. (2014) "The Political Culture of Democracy in Jamaica and in the Americas, 2014: Democratic Governance across 10 Years of the Americas Barometer." Centre for Leadership \& Governance, University of the West Indies, Mona, April 2015.

https://www.vanderbilt.edu/lapop/jamaica/AB2014_Jamaica_Executive_Summary_Fo rmatted_V3_W_082115.pdf.

HARRIOTT, A., and MARLYN, J. (2016) "Crime and Violence in Jamaica: IDB Series on Crime and Violence in the Caribbean." Inter-American Development Bank, June 2016. https://doi.org/10.18235/0000333.

GLAISTER, L. Confronting the Don: the Political Economy of Gang Violence in Jamaica. Geneva: Small Arms Survey, 2010. Mataković H, Matakovic Cunjak, I. (2019) "The Impact of Crime on Security in Tourism." Security and Defence Quarterly, 2019, 1-20. https://doi.org/10.35467/sdq/115539.

ICINDA NEIL, J. A. (2018) "IUU Fishing: a Gateway to Transnational Crimes in Jamaica." The Maritime Commons: Digital Repository of the World Maritime University, November 4, 2018. https://commons.wmu.se/all_dissertations/657.

JAFFE, R. (2019) "Writing around Violence: Representing Organized Crime in Kingston, Jamaica." Ethnography 20, no. 3 (November 2019): 379-96. https://doi.org/10.1177/1466138118818585.

JAITMAN, L., DINO, C., GRANDGUILLHOMA OCHOA, R., KEEFER, P., LEGGET, T., LEWIS, J. A., MEJIA GUERRA, J. A., MELlO, M., SUTTON, H., and TORRE, I. (2017)"The Costs of Crime and Violence: New Evidence and Insights in Latin America and the Caribbean." Inter-American Development Bank, 2017. https://doi.org/10.18235/0000615.

JOHNSON, H. N., JOSEPH, L. S. (2008). "Jamaican Dons, Italian Godfathers and the Chances of a "Reversible Destiny". Roger Williams University. Political Studies 56 (1): 166-191 https://docs.rwu.edu/cgi/viewcontent.cgi? article $=1186 \&$ context $=f c a s \_f p$

LEE, A., DELATIE BUDAIR, L. (2018). "Statistical Annex." Voluntary National Review Report on the Implementation of the 2030 Agenda for Sustainable Development, June 2018. https://doi.org/10.1787/empl_outlook-2018-11-en.

LEGGETT, T., VAN BRONKHORST, B., DEMOMBYNES, G., MORRISON, A. (2007) "Crime, Violence, and Development: Trends, Costs, and Policy Options in the Caribbean." United National Office of Drugs and Crime (UNODC), no. 37820 (March 2007). https://www.unodc.org/pdf/research/Cr_and_Vio_Car_E.pdf.

MORRIS, P., GRAYCAR, A. (2011). Homicide Through A Different Lens. British Journal of Criminology. 51. 823-838. DOI: 10.1093/bjc/azr038.

NIGEL, C., MARISSON, D. "The Citizen's Guide to the Budget 2020-2021.” Ministry of Finance \& Public Service. Accessed April 13, 2020. https://mof.gov.jm/documents/documents-publications/document-centre/file/2356-thecitizen-s-guide-to-the-budget-2020-2021.html.

National Security Policy for Jamaica (2017). "Towards a Secure \& Prosperous Nation" Government of Jamaica, 2007. https://www.oas.org/csh/spanish/documentos/National Security Policy - Jamaica - 2007.pdf. 
O'REILly, P., and O'REILly, E. (2020) "InSight Crime's 2019 Homicide Round-Up." InSight Crime, February 4, 2020. https://www.insightcrime.org/news/analysis/insightcrime-2019-homicide-round-up/.

OSAC (2019) “Jamaica 2019 Crime \& Safety Report.” OSAC. Overseas Advisory Council, May 30, 2019.

https://www.osac.gov/Country/Jamaica/Content/Detail/Report/1d98b2df-fd4b-485faa62-15f4aed245ef

TIFFANY, A. “Ja's Budget 2014 In A Nutshell -.” diG Jamaica, July 19, 2018. http://digjamaica.com/m/blog/jas-budget-2014-in-a-nutshell/.

UN (2017). "United Nations, Department of Economic and Social Affairs, Population Division 2017'. Household Size and Composition Around the World 2017 - Data Booklet https://www.un.org/en/development/desa/population/publications/pdf/ageing/househol d_size_and_composition_around_the_worl d_2017_data_booklet.pdf

USDOS (2019). "Jamaica Travel Advisory." U.S. Department of State. U.S. Department of State, April 15, 2019.

https://travel.state.gov/content/travel/en/traveladvisories/traveladvisories/jamaicatravel-advisory.html.

WITBOOI, E. (2020). “CRIMINALITY AND RESILIENCE: Rocky Point, Jamaica.” Global Initiative Against Transnational Organized Crime, February 2020. https://globalinitiative.net/wp-content/uploads/2020/02/Jamaica-report.19.02.v3.pdf.

World Bank (2019) “The World Bank In Jamaica - Overview. October 7, 2019. https://www.worldbank.org/en/country/jamaica/overview\#1.

WTTC (2017). "Jamaica - How Does Travel \& Tourism Compare to Other Sectors?" World Travel \& Tourism Council, 2017. https://www.wttc.org//media/files/reports/benchmark-reports/country-reports-2017/jamaica.pdf.

WTTC (2020). “Jamaica - 2020 Annual Research: Key Highlights.” World Travel \& Tourism Council 2020 file:///C:/Users/hadzibse/Downloads/Jamaica 2020.pdf 
